DOI: 10.32370/IA_2021_09_12

\title{
Conceptual Technologies of Application of Coaching Technology in Public Administration
}

\author{
Maria Surzhyk \\ Postgraduate student \\ of the Educational and Scientific Institute of Public Administration and \\ Civil Service of Taras Shevchenko National University of Kyiv \\ Kyiv, Ukraine \\ E-mail: surzhykmaria77777@ gmail.com \\ ORCID ID https://orcid.org/0000-0002-8812-1581
}

\begin{abstract}
The article reveals the concept of coaching as an innovative technology of public administration. The technology is based on a democratic leadership style, formed by systematic thinking and a somewhat organized technique of questions, which ultimately focuses on the prospect of positive change and optimization of production relations, based on cooperation and feedback.

The global goal of coaching in public administration is defined, which provides constant updating of skills of managerial competence and successful leadership through the formation of worldview, adoption of holistic attitudes, a certain culture of communication and interaction, motivation.

The effectiveness of the use of coaching technology in public administration is substantiated.

The main further prospects of work on the research are determined. Develop scales of indicators for evaluating the effectiveness of coaching technology in public administration.
\end{abstract}

Keywords: coaching, coaching models, public administration,

Постановка проблеми в загальному вигляді та ї̈ зв'язок із важливими науковими чи практичними завданнями. У процесі зростання інтелектуалізації, виконання завдань високого рівня складності, вміння швидко адаптуватись до нових умов, мислити критично та нестандартно, володіти високим рівнем стресостійкості, комунікабельності, прагнення до навчання протягом життя $є$ принциповими вимогами, які постають перед сучасною політичною елітою у процесі державотворення. Відповідно, виникає потреба і у пошуку нових форм вдосконалення професійних навичок, компетенцій у будь-яких органах влади. Перед представниками публічної влади щоденно постає необхідність глибокого аналізу соціально-психологічних факторів управлінської діяльності. До загальних компетенцій стоїть гостра потреба додати індивідуально-психологічні особливості працівників, усвідомлення та інтерпретація ситуацій, що виникають під час реалізації державно-владних повноважень, володіння навичками конструктивної комунікації, ведення переговорів, врегулювання конфліктних ситуацій тощо. 
Компетенції необхідно розуміти як наявну здатність із погляду знань, умінь, навичок і установок, яка забезпечує реалізацію професійних завдань на високому рівні, відповідність законодавству. Науковці визначають близько 86 професійних компетенцій державних службовців. Більшість з них дотримується думки, що саме коучинг $є$ тією технологією управління, яка дозволяє сформувати необхідні компетенції представникам органів державної влади та суттєво вплинути на ефективність діяльності в цілому.

В останнє десятиліття в Україні саме поняття і навчання коучингу, як професії, набирає все більшої популярності.

Аналіз останніх досліджень $\boldsymbol{i}$ публікацій. Питаннями результативності застосування коучингу в управлінській діяльності займалися зарубіжні науковці: Дж. Уітмор, Т. Голві, Л. Уітворт, який обгрунтував відмінність поняття коучингу від менторства та наставництва. Його дослідження продовжили Г. Кімсі-Хаус, М. Ландсберг, Д. Роберт та інші. Дослідження цих авторів містять способи реалізації коучингової взаємодії, методи застосування коучингу, окремі аспекти 3 оцінювання елементів коучингу. Серед вітчизняних науковців варто відзначити праці: О. Кузьміна, Н. Чухрай, В. Павлова, Л. Круглова, В. Гурієвської та інші. В. Гурієвською здійснено аналіз можливостей застосування технології коучингу в системі державного управління та підвищення кваліфікації державних службовців. Науковці висвітлили трактування поняття «коучингу», особливості його застосування, рекомендації щодо розвитку потенціалу працівників із застосуванням даного методу.

Цілі статті. Основною метою статті є охарактеризувати коучинг як технологію державного управління; обгрунтувати ефективність використання технології коучингу в публічному управлінні; охарактеризувати основні підходи застосування коучингу в світовій та Українській практиці.

\section{Виклад основного матеріалу дослідження.}

Сьогодні коучинг - звичне явище як у сфері бізнесу, де він активно використовується у сфері управління людськими ресурсами (HR-менеджмент), у роботі 3 бізнесконсультантами, аудиторами, фахівцями з підбору персоналу, так і в інших сферах людського життя: освіті, спорті, особистому житті тощо [5, с.8].

Основоположником коучингу вважається Джон Уітмор, який в 1992 р видав книгу "Коучинг високої ефективності" після видання якої розпочинається активне вивчення 
науковцями основних понять та підходів у застосуванні. Уітмор, як минулий спортсмен, виділив схожі підходи у досягненні результатів спортивних та професійних через ідеї Тіма Геллвея, творця теорії "Внутрішньої гри" (Inner Games), про психологічні тренуваннях спортсменів. Т. Голві у своїй книзі пише, що ідея внутрішньої гри спала йому на думку під час роботи тренером із тенісу.

Основним меседжем підходу коучингу стає усвідомлення того, що гравець (учень) вже володіє всіма природними задатками, необхідними для подолання внутрішнього супротиву та досягнення високих результатів своєї діяльності. Тому ключовим завданням коуча стає створення оптимальних умов до реалізації потенціалу підопічного.

Наразі питання глобальних та швидкісних змін ще не стояло так гостро, як сьогодні.

Бурхливий розвиток компаній доткомів (dotcom, dot-com, dot.com), що розпочався наприкінці 90-х рр.. ХХ століття) спричинив революційний перехід від звичних механізмів прийняття управлінських рішень, на які потрібно витрачати забагато часового ресурсу, що в подальшому впливає на ефективність результату та своєчасність прийняття рішень.

Відповідно до цього виникає потреба у пошуку таких нових напрямів, які будуть впливати на високу ефективність, що розуміється у зниженні перешкод та підвищення потенціалу.

Відповідно до вищезазначеної теорії Т. Голві, коучинг - це методика розкриття потенціалу особистості для максимізації власної продуктивності та ефективності. Сьогодні, це поняття розкривається при більш глибинному дослідженні. «Незважаючи на існування Міжнародної федерації коучингу (ICF) з представниками у 138 країнах, якщо переглянути слово «соасh» чи «coaching» на інтернет-сторінці Оксфордського словника, ми практично нічого не дізнаємося про те, чим саме ці люди займаються. Словник пропонує два визначення. Перше - це автобус далекого сполучення, вагон поїзду та спосіб переміщення. Друге визначення говорить про спортивний інструктаж та навчання, приватних чи додаткових уроках... В коучингу рух - все, а інструктаж та навчання - майже нічого», - говорить Джон Уітмор [6, с.24].

Нестандартність визначення терміну коучингу готує нас до того, що і сам метод змушує шукати нестандартні, креативні підходи, які виходять за рамки стандартного 
сприйняття, при цьому дотримуючись основної мети - підвищення результатів, а головним питанням залинити - як найкраще досягнути цієї мети та утримати результат.

В управлінській практиці можливості застосування коучингу надзвичайно широкі: мотивація працівників, оцінка і атестація; делегування повноважень, виконання завдання; рішення проблем, планування і контроль; питання взаємин, розвиток працівників; створення команди, групова робота.

Коучинг можна проводити до, після і під час виконання робіт. Він може проходити спонтанно, тривати одну хвилину або цілу годину. Таким чином, головний інструмент для керівника, який хоче «включити мозок» своїх співробітників, це ефективні питання $[4, \mathrm{c.4}]$.

«У більшості випадків коучинг застосовується на підприємствах в ролі унікального системного підходу до утворення корпоративної культури, методів розвитку співробітників, створення і реалізації стратегій підприємств. За винятком цього, керівники, які використовують метод коучингу як метод управління персоналом, мають можливість найбільш простіше і ефективніше утримати цінних працівників у своїй організації, тим самим знижуючи плинність кадрів. Коучинг можна застосовувати до всіх співробітників організації, але особливо він є необхідним для таких категорій, як: керівники, успішні співробітники, працівники, яким необхідні нові навички.

Безсумнівно, впровадження коучингу в організаціях повинно починатися 3 керівників та керівників підрозділів.

Коучинг для керівників вищої та середньої ланки проводиться з метою: розвитку управлінських навичок; впровадження коучингу в систему організації діяльності; залучення співробітників в роботу організації; адаптації нових керівників; розвитку системного мислення» $[4$, с.5].

Отже, коучинг - це організований, цілеспрямований процес, який орієнтований на досягнення максимально можливого результату, 3 використанням, безпосередньо, внутрішнього потенціалу людини з опорою на зовнішні умови.

Сучасний рівень розвитку держави нерозривно зв'язаний із розвитком освіти, науки, інновацій та має базуватися на інтеграції науки, психології, практики. «управлінської діяльності та розкриває зміст когнітивної і інноваційної складової державного управління [3, с.33]. 
Аналізуючи різні підходи до визначення поняття коучинг в Такий підхід до державно-управлінської діяльності потребує розглядати технології коучингу як об'єкт науки державного управління, оскільки це дає змогу вивчати і враховувати соціальнопсихологічні складові державноуправлінській діяльності ми приходимо до висновку, що коучинг в системі державного управління - це технологія, яка «базується на демократичному стилі керівництва, сформованому системному мисленні та певним чином організованій техніці запитань, що в кінцевому підсумку орієнтована на перспективу позитивних змін та оптимізацію виробничих відносин, на основі співробітництва і налагодження зворотного зв'язку. 3 іншого боку, коучинг - це компетенція менеджменту та стиль лідерства, що допомагає управлінцям реалізовувати цілі та розвиватися через взаємодію [3, с.36].

Глобальна мета коучингу в державному управлінні передбачає постійне оновлення навичок управлінської компетентності та успішного керівництва через формування світогляду, прийняття цілісних установок, певну культуру у спілкуванні та взаємодії, мотивації. Крім того, через такі глобальні аспекти формуються індивідуальні якості управлінця, що виражаються в усвідомленні власних дій та мотивів, делегуванні відповідальності, ефективності використання часового ресурсу, вдосконалення власних професійних навичок та вдосконалення інтелектуального рівня з виходом на високий рівень індивідуальної задоволеності від процесу управлінської діяльності [3, с.37].

Коучинг у системі органів державної влади - це спеціально організований процес надання допомоги керівникам, колективу (чи групі осіб) у розв'язанні проблем державноуправлінської діяльності, як послуги, що їх надають незалежні спеціалісти, та як засіб підвищення соціально-психологічної компетенції управлінців [2].

Коучинг в організаціях $\epsilon$ соціально-управлінським інструментом розвитку публічних управлінців, спрямованим на поліпшення кількісних і якісних характеристик діяльності, удосконалення професійних і особистісних навичок як керівників, так i звичайних працівників. Досвід багатьох іноземних компаній свідчить, що використання коучингу в управлінні персоналом дає змогу підвищити ефективність роботи, вдосконалити професійні та особисті навички співробітників.

Впровадження коучингу як методу управління дає змогу здійснити якісні зміни в компаніях, а саме: вивести відносини керівників з підлеглими на рівень «дорослий - 
дорослий», створити умови для щирості та відкритості всіх учасників процесу; сформувати відповідальність у співробітників за прийняті рішення i отриманий результат; надати можливість працівникам управляти своєю працею: розподіляти час, визначати необхідні ресурси, що розкриє внутрішній потенціал співробітників, створить внутрішню мотивацію, а також підвищить задоволеність від роботи; по-іншому поглянути на своє життя, підвищити його якість, позбутися внутрішніх бар'єрів, що перешкоджають досягненню цілей, і навчитися знаходити власні ресурси як керівникам, так і їх підлеглим.

В Україні на сьогодні відсутнє державне регулювання сфери коучингу, оскільки у класифікаторі професій відсутня така професія як коучер. Діяльність коучера регламентована лише вид надання інформаційних та консультаційних послуг. Наразі стоїть гостро питання підготовки таких спеціалістів в Україні. Діючі тренери-коучі, які надіють послуги відповідно рівня, мають переважно підготовку закордонних фахівців. Стримуючим фактором розвитку коучингу $є$ те, що вітчизняні бізнес-структури до дослідили достатньо глибоко специфіку діяльності таких тренерів та не залучають їх до своєї діяльності. На території України бізнес-коучерів активно залучають лише транснаціональні корпорації та компанії з іноземними інвесторами.

Висновки. Отже, коучинг в системі органів державної влади спрямований на забезпечення високих стандартів виконання завдань, створення атмосфери, яка стимулює креативність, генерацію нових ідей i $\epsilon$ надійним фундаментом інтегрованості працівників, так як проявляється через підтримку, співпрацю та партнерство, допомагає набути нових конкурентних переваг.

Перспективи подальших розвідок у даному напрямі ми вбачаємо в подальшій розробці шкали індикаторів оцінювання результативності застосування технології коучингу в публічно-управлінській діяльності.

\section{References}

1. Coaching is a tool for personal and professional development.: http://www.lifecoach.com.ua.

2. Gurievskaya, V. (2010). Technologies of psychological counseling in public authorities of Ukraine. Mechanisms of public administration. Kyiv. 
3. Gurievskaya, V. (2011). Coaching as an applied technology of public administration. Bulletin of the National Academy of Public Administration, 1, 32-39.

4. Karminska-Belobrova, M. (2018). Coaching as an innovative tool for management development in Ukraine. Bulletin of the National Technical University "Kharkiv Polytechnic Institute" (economics, 47 (1323), 3-7.

5. Nezhyns'ka, O., Tymenko, V. (2017). Basics of coaching: a textbook. Kyiv. DISA PLUS.

6. Whitmore, D. (2019). Coaching. Basic principles and practices of coaching and leadership. Moscow: Alpina Publisher.

\section{$\underline{\text { Translation of name and affiliation to author's language }}$}

\section{Марія Суржик}

аспірант Навчально-наукового інститут публічного управління та державної служби Киїського національного університету імені Тараса Шевченка 